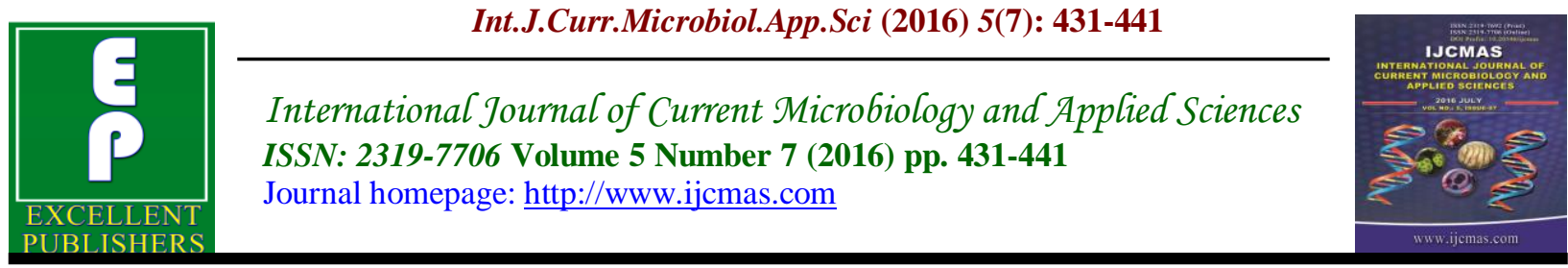

Original Research Article

http://dx.doi.org/10.20546/ijcmas.2016.507.047

\title{
Microorganisms Responsible of Diabetic Foot Infection in Taiz City, Yemen
}

\author{
Mohammed A. Al-Hegami ${ }^{1}$, Saeed M.S. Alghalibi ${ }^{2}$ and Abdullah Al-Mamari ${ }^{3} *$ \\ ${ }^{1}$ Department of Science, Faculty of Education, Sana'a University, Yemen \\ ${ }^{2}$ Biology Department, Faculty of Science, Sana'a University, Yemen \\ ${ }^{3}$ Department of Biological Sciences, Faculty of Science, Ibb University, Yemen \\ *Corresponding author
}

\begin{abstract}
A B S T R A C T
\section{Keywords}

Diabetic foot infections, microorganisms, DFI,

Taiz, Yemen.

\section{Article Info}

Accepted:

15 June 2016

Available Online:

10 July 2016

Diabetic foot infections (DFI) are normally caused by microorganisms. They are usually inadequately managed due to misunderstanding of microbial prevalence and therapeutic approaches. This study aimed to detect pathogenic microorganisms in diabetic foot infection (DFI) of some Yemeni patients in Taiz City, and to investigate the sensitivity of isolated microorganisms to different antibiotics. Eighty samples were collected from (DFI) patients admitted in AL-Thowra hospital, and Al-Gomhory Hospital in Taiz City through study period. The rates of patients who got diabetic foot infection were $61 \%$ males and $39 \%$ females. Their ages range between $32-85$ years. The ratio of patients who got amputation was $26 \%$. Gram positive bacteria were responsible of $67 \%$ of DFI cases followed by Gram negative bacteria in $28 \%$ and yeasts in $5 \%$ of cases. The most commonly isolated microorganisms from the diabetic foot ulcers were Pseudomonas aeruginosa $(37.8 \%)$ and Staphylococcus aureus (18.9\%), followed by Escherichia coli $(11.1 \%)$, Klebsiella pneumoniae $(11.1 \%)$ and Candida albicans $(5.6 \%)$. Other isolates were recorded in low frequencies.
\end{abstract}

\section{Introduction}

Diabetes Mellitus (DM) is a progressive disease worldwide and remains an important cause of morbidity, mortality and major lower extremity amputation at some stage of life (Caputo et al., 1997). The number of diabetic patients (DP) worldwide in 2007, about 246 million infected, and is expected to amount to more than 350 million in 2025 (Rubaiaan, 2008).

Diabetes is a chronic disease that affects on about 14 million Americans and increasing in population to the point where public health authorities are calling diabetes an" epidemic" that requires argent attention. Every year, 600,000 additional cases are diagnosed (Bennett, 1999). Diabetes drain $33 \%$ of health budgets in European countries and cost the United State of Americans (USA) 115 billion dollars (\$) annually. In kingdom Saudi Arabia, the rate of infection $24.7 \%$ a year and annual growth rate of DP are about 1\% (Rubaiaan, 2008).

Diabetic foot infection (DFI) defined as the disease caused by a microbial pathogen that 
occurs when the presence of replicating organisms is associated with tissue damage (White, et al., 2001). Other definition, DFI is the presence of multiplying bacteria in body tissues, resulting in spreading cellular injury due to competitive metabolism, toxins, intracellular replication, or antigenantibody response (Ayton, 1985).

DFI causes a major public health problem and impose a heave burden on health services and own family. It is responsible on patient hospital admission, drain of future earning power, major foot amputations, disability, loss work, family fragmentation, and eventually death (Caputo et al., 1997). In USA in 2001, over one million amputations per year, every 30 seconds a leg is lost, 50\% amputees undergo second amputation, and 50\% amputees die 2-5 years after amputation (Johonson and Citron, 2002).

In1990, over 54000 lower extremity amputations accrued among diabetics (8.3 per 1000). Medical cost of treatment of the DF $\$ 85$ billion (average of $\$ 45,000$ per patient) (Josef and Nesbit 1998).

In kingdom Saudi Arabia, the direct cost of DM is expected (5.9) billion riyals a year. $\mathrm{DM}$ is first cause for the foot amputations and depression, $20 \%$ of the mothers after the pregnancy is development of diabetes and $9 \%$ of patients die annually (Rubaiaan, 2008).

Microorganisms can cause the ulcers of DM patients to become very inflamed, sore and delay healing include: aerobes bacteria such as Streptococcus pyogens, Staphylococcus aureus, Pseudomonas aeruginosa, Proteus mirabilis, Escherichia coli, Klebsiella pneumonia. Anaerobes bacteria are Clostridium perfringens, Bacteriodes fragilis and yeast is Candida albicans.
Infections in patients with diabetes are difficult to treat because these patients have weakness in microvascular circulation, which limits the access of phagocytic cells to the infected area and results a poor concentration of antibiotics in the infected tissues (Marble and Alexander, 1985).

Detection of pathogenic microorganisms in diabetic foot infection (DFI) of some Yemeni patients.

\section{Specific objective's}

To study the relative frequency of bacterial isolates cultured from diabetic foot infections. And to determine the effect of some medicinal plant extracts collected from Taiz province and some chemical antiseptics on isolated microorganisms.

\section{Materials and methods}

Sample size: A total of 80 patients suffered from DFI were enrolled in this study. The age of the studied patients ranges from 32 to 85 years old.

Setting: This study was conducted in ALThowra, and Al-Gomhory Hospitals in Taiz city were the patient's admission to these Hospitals and the specimens were transported to Central Public Health Laboratory Taiz Branch - Yemen to isolate microorganisms.

Study design: A cross sectional descriptive study was conducted during the period from December 2007 till November 2008.

Sampling techniques: Both the ulcer and surrounding skin area were cleaned using swab soaked in $70 \%$ of ethanol alcohol. Two sterile dry cotton wool swabs were used to collect samples of purulent secretions from DF ulcer. The swabs were moistened with 
sterile physiological saline and rubbed on the wound surface, then one of the swabs was placed into sterile bottle container contain Cooked Meat broth medium, labeled with the date, time of collection, the patient's name, number of sample, and incubated for 24-48h at $35-37{ }^{\circ} \mathrm{C}$ and inspected daily for growth. The other swab was placed into sterile plastic container, labeled with the date, time of collection, the patient's name, and number of sample. The specimens sent to the laboratory with accompanied request form that belongs to the patient. Specimens were cultivated as soon as possible (Cheesbrough, 2000 and Slater, et al., 2004).

\section{Culturing and isolation of the specimens}

If found growth in Cooked Meat broth medium was inoculated on to two culture media as following: Neomycin blood agar plate for isolation of anaerobic bacteria such as $C$. perfringens and B. fragilis. Other blood agar plates for the isolation other anaerobic bacteria and incubated in anaerobic jar for $48 \mathrm{~h}$ at $35-37{ }^{\circ} \mathrm{C}$ and inspected daily for growth (Vandepitte, 2003).

The other swab was cultivated as soon as possible onto a blood agar plate for the isolation of Gram-positive and Gramnegative bacteria and MacConkey agar plate for the isolation of Gram-negative bacteria and incubated aerobic for $24-48 \mathrm{~h}$ at $35-37^{\circ} \mathrm{C}$ (Frykberg, 2003).. Microorganism that was isolated from (DFU) may belong to almost any group or species. The following steps will provide a framework within us able to identify any bacterial species.

\section{Effect of some plant extracts on the growth of the isolated bacteria}

Eleventh species of medicinal plants were collected from Taiz Government shows in Table 1.
The part of plants used were aerial parts in all plants, except Juniperus procera plant and material used was exudates of plant (Aldbai and Alkhalidi, 1996; Environmental Protection Authority, 2002 and Tomei, et al., 2003).

Collected plants were air-dried at room temperature, ground into powder by using a sterile electric grinder. The powder was extracted by solubilization method as following:

\section{Water extraction}

Cool water extraction: ten grams of powder plant added to $100 \mathrm{ml}$ of cool distilled water and extracted by shaking at room temperature for $8 \mathrm{~h}$ daily to three day. Extract was dried by evaporator on slow heat.

Heat water extraction: ten grams of powder plant added to $100 \mathrm{ml}$ of heat distilled water and extracted by shaking at $60{ }^{\circ} \mathrm{C}$ for $8 \mathrm{~h}$ daily to three day. Extract was dried by evaporator on slow heat (Lazrek, et al., 2005).

Methanol extraction: Ten grams of powder plant were dissolved with $100 \mathrm{ml}$ methanol $(99 \%)$ and extracted by shaking at $50{ }^{\circ} \mathrm{C}$ for $2 \mathrm{~h}$ daily to three day. Extract was dried by evaporator at $60{ }^{\circ} \mathrm{C}$. One Hundred disks were Prepared $(5.25 \mathrm{~mm}$ diameter) of whatman filter paper by used borer. Put each 100 disk in test tub then closed it and sterilized by dry temperature at $140^{\circ} \mathrm{C}$ to $1 \mathrm{~h}$.

Dissolved 1g of extracted material in $10 \mathrm{ml}$ of solvent (distilled water or methanol), then taken $1 \mathrm{ml}$ of solution and input to disks in test tub. Each disk had $1 \mathrm{~g}$ of extracted material.

\section{Statically analysis}

Analysis of the data was performed by SSPS 
version 12. Statistical significance was set at Asymp. Sig. < 0.05 was considered significant.

\section{Results and Discussion}

\section{Distribution of DFI cases according to the age and sex}

The distribution of DFI cases according to the age and sex is shown in Table 2. In general, the patients were elderly their age ranged from 32 to 85 years old. The highest distribution of DFI cases were found in age group 61-70 years (30\%) of both males and females equally, followed by age group 5160 years $(26.3 \%)$ were difference in ratio male $(17.5 \%)$ to females $(8.7 \%)$ and age group $41-50$ years $(23.7 \%)$ were similar in both gender.

The relationship occurrence of DFI with respect to age and gender of the patients was without statistical significant.

\section{Microorganisms isolated from DFI}

Out of 90 isolates, the Gram-negative bacteria was presented in $60(66.7 \%)$ isolates, followed by gram-positive bacteria $25(27.7 \%)$, and the lowest number found in yeast $5(5.6 \%)$ isolates.

A total of 90 pathogenic microorganisms were isolated from 80 DFI cases. The organisms that were isolated from DFI are presented in Table 3. The most commonly isolated bacteria and fungi from the diabetic foot ulcers were $P$. aeruginosa 34 (37.8\%), S. aureus 17 (18.9\%), E. coli 10 (11.1\%), K. pneumoniae 10 (11.1\%), C. albicans 5 (5.6\%), P. mirabilis 4 (4.4\%) and Group $\beta$ Streptococci 4 (4.4\%). B. fragilis, $S$. epidermidis and $C$. perfringes were isolated in low frequency (2.2\% for each). The relationship between microorganisms isolated was significant.

\section{Microorganisms isolated from monomicrobial growth cultures}

Table 4 shows 70 (87\%) of patients had monomicrobial infection. The highest prevalent of microorganisms isolated from DFI patients with one isolated microorganisms were $P$. aeruginosa isolated from 31 patients $(44.3 \%)$ which isolated equally in both gender or rise relatively in females than males followed by $S$. aureus isolated from 13 patients $(18.6 \%)$ and rise relatively in males than females. E. coli recovered in 10 patients $(14.3 \%), K$. pneumonia in 9 patients $(12.8 \%)$, and $C$. albicans in 5 patients (7.1\%). The low frequency was Group $\beta$ Streptococci recovered in 2 patients $(2.9 \%)$. Distribution of monomicrobial growth according to gender was without statistical significant.

\section{Microorganisms isolated from polymicrobial growth cultures}

Polymicrobial growth cultures were found in $10(13 \%)$ of patients as shows as in Table 5. The most commonly isolated organism from polymicrobial growth was $S$. auerus associated with $P$. mirabilis in two patients $20 \%$, with S. epidermidis in one patient $10 \%$ and with $B$. fragilis in one patient $10 \%$. $P$. aeruginosa associated with $P$. mirabilis in two patient $20 \%$ and with $B$. fragilis in one patient $10 \%$. K. pneumonia associated with S. epidermidis in one patient $10 \%$. Group $\beta$ Streptococci associated with $C$. perfringes in two patients $20 \%$.

\section{Effects of some medicinal plant extracts on isolated microorganism}

The effects of some medicinal plant extracts were studied against 4 common isolated bacteria from DFI patients $(P$. aeruginosa, $S$. aureus, E. coli and K. pneumonia). From 11 medicinal plants extracts, 9 plants extracts had no activity against the 4 isolated 
bacteria. These plants are Jatropha curcas, Calotropis procera, Ziziphus spina-christii, Copparis catilaginea - decne, Pulicaria undulate, Tribulus terrestris, Withania somnifera, Chenopodium murale and Pergularia tomentosa.

Kleinia adora and Juniperus procera plants, aqueous and methanolic extracts showed antibacterial activity against tested bacteria. These extracts had activity against tested bacteria (inhibition zone was surrounded discs and measured in $\mathrm{mm}$ ) when plant extracts were at concentration only. The cold water extract of Kleinia adora had high activity against isolated bacteria, while methanolic and hot water extracts had low activity on isolated bacteria.

The methanolic and hot water extracts of Juniperus procera plant were more effective against isolated bacteria from cold water extract.

The plants extracts that had no activity against the 4 isolated bacteria, Then did mixed of medicinal plant extracts together as following; Two medicinal plant extracts were mixed together then tested and mixed third extract with both then tested....etc respectively. These serials mixed were studied against microorganisms isolated. The results were also negative in all isolated microorganisms.

The big problem was that bacteria do not respond well to antibiotic treatment due to high numbers of microorganisms' colonization in foot. The type, and dose of antibiotic that used for treatment DFI, must be suitable with the microbial colonization (Lipske, et al., 2005).

This study showed that patients were elderly and their ages ranged from 32 to 85 years. Similar observation was also reported in Osztaly, Saudi Arabia, Kuwait and in Nepal by Kajetan, et al., (1995); El-Tahawy, (2000); Abdulrazak, et al., (2005) and Sharma, et al., (2006). 49 (61\%) of patients were males and 31(39\%) were females. The males were more infected with DFU due to males don't care in their foot and more travel than females. These findings consistent with previous study in Osztaly (Hungary) in ratio of males to females and their ages (Kajetan et al., 1995).

Concerning age groups, the ratio of males to females were similar in the age group 61-70 year, and age group 41-50 year, and difference in age group 31-40 year and age group $>71$ year (Table 2). This similar and difference between rates males to females in several age groups of DF patients may be refer to number of males to females, found previous fungal skin infection among fingers or on back of the foot and debilitated patients.

The general objective in this study was to detection of pathogenic microorganisms in diabetic foot infection (DFI) of some Yemen patients. In this study bacteria and fungi that cause DFI were studied and the results showed that all patients have one or more pathogenic microorganisms. Similar finding were also reported in Saudi Arabia (ElTahawy, 2000), in Kuwait (Abdulrazak, et al., 2005), and in Nepal (Sharma, et al., 2006) who found that DFI patients had one or more pathogenic microorganisms. Refer to elevated of carbohydrates level in blood and body cells (hyperglycemia) and foot complications were the main reasons for these infections. The microorganism that isolated from DFI were $P$. aeruginosa, $S$. aureus, E. coli, K. pneumonia, C. albicans, $P$. mirabilis, Group $\beta$ Streptococci, $B$. fragilis, $S$. epidermidis and $C$. perfringes (Table 5).

DF ulcers were exposed to skin commensals, and there microflora 
represented the surrounding environment. The contaminated microbes can quickly become established within a wound, reaching a state of colonization (Palumbo and Melton, 1985).

Aerobic Gram-positive bacteria including $S$. aureus, $S$. pyogenes, strict anaerobic bacteria and aerobic Gram-negative bacilli frequently cause infections in patients with diabetes (Joshi, 1999). Some bacteria (such as Enterococcus spp.) were reported in Kuwait study (Abdulrazak, et al., 2005), but in this study this bacteria was not isolated from DFI.
The first goal in this study was to study the relative frequency of bacterial isolates cultured from diabetic foot infections. In this study, Gram-negative bacilli were the dominant pathogens found in $66.7 \%$ of DFU cases, while Gram-positive bacteria were isolated from $27.7 \%$ of the cases and yeasts were isolated from $5.6 \%$ of the cases as shown as in Figure 6. These rates of isolated pathogens were contrasted compared with previous studies in Osztaly, Saudi Arabia, Kuwait and in Nepal (Kajetan, et al., 1995; El-Tahawy, 2000; Abdulrazak, et al., 2005 and Sharma, et al., 2006).

Table.1 Medicinal plants used in this investigation against isolated bacteria

\begin{tabular}{|l||l||l||}
\hline \multicolumn{1}{|c|}{ Scientific name } & \multicolumn{1}{c||}{ Family name } & \multicolumn{1}{c||}{ Arabic name } \\
\hline \hline Jatropha curcas & Euphoriaceae & Sharpa \\
\hline Calotropis procera & Asclepiadceae & Ushar \\
\hline Ziziphus spina-christii & Rhamnaceae & Sidr \\
\hline Copparis catilaginea -decne & Copparidaceae & Rusaf \\
\hline Pulicaria undulate & Asteraceae & Jeth Jath \\
\hline Tribulus terrestris & Zygophyllaceae & Hasak or Qutiba \\
\hline Withania somnifera & Solanaceae & Ubab \\
\hline Chenopodium murale & Chenopiaceae & Zurpikh \\
\hline Pergularia tomentosa & Asclepiadaceae & Ghulqa \\
\hline Juniperus procera & Cupreffaceae & Ferwish \\
\hline Kleinia adora & Asteraceae & Adhkher \\
\hline \hline
\end{tabular}

Table.2 Distribution of DFI cases according to the age groups and sex.

\begin{tabular}{|c|c|c|c|c|c|c|c|c|c|}
\hline \multirow{2}{*}{$\begin{array}{l}\text { Age groups } \\
\text { (years) }\end{array}$} & \multicolumn{2}{|c|}{$\begin{array}{c}\text { Male } \\
(n=49)\end{array}$} & \multicolumn{2}{|c|}{$\begin{array}{l}\text { Female } \\
(n=31)\end{array}$} & \multicolumn{2}{|c|}{$\begin{array}{l}\text { Total of cases } \\
\quad(n=80)\end{array}$} & \multirow{2}{*}{$\underset{\text { Value }}{P_{-}}$} & \multirow[t]{2}{*}{ df } & \multirow{2}{*}{$\begin{array}{l}\text { Asymp } \\
\text { Sig. }\end{array}$} \\
\hline & N. & $\%$ & N. & $\%$ & N. & $\%$ & & & \\
\hline$<\mathbf{3 0}$ & 0 & 0 & 0 & 0 & $\overline{\overline{0}}$ & $\overline{0}$ & \multirow{7}{*}{6.122} & \multirow{7}{*}{5} & \multirow{7}{*}{.294} \\
\hline $31-40$ & 5 & 6.2 & 2 & 2.6 & 7 & 8.7 & & & \\
\hline $41-50$ & 10 & 12.5 & 9 & 11.3 & 19 & 23.7 & & & \\
\hline $51-60$ & 14 & 17.5 & 7 & 8.7 & 21 & 26.3 & & & \\
\hline 61-70 & 12 & 15 & 12 & 15 & 24 & 30.0 & & & \\
\hline$>71$ & 8 & 10 & 1 & 1.2 & 9 & 11.2 & & & \\
\hline Total & 49 & 61.2 & 31 & 38.8 & 80 & 100 & & & \\
\hline
\end{tabular}


Table.3 Frequency of pathogenic microorganism isolated from 80 DFU patients.

\begin{tabular}{|c|c|c|c|c|c|}
\hline Microorganism & Frequency & Percent & $\underset{\text { Value }}{P_{-}}$ & df & $\begin{array}{c}\text { Asymp. } \\
\text { Sig. }\end{array}$ \\
\hline Gram-negative bacteria & 60 & 66.7 & \multirow{13}{*}{117.29} & \multirow{13}{*}{9} & \multirow{13}{*}{.00} \\
\hline Pseudomonas aeruginosa & 34 & 37.8 & & & \\
\hline Escherichia coli & 10 & 11.1 & & & \\
\hline Klebsiella pneumonia & 10 & 11.1 & & & \\
\hline Proteus mirabilis & 4 & 4.4 & & & \\
\hline Bacteriodes fragilis (anaerobic) & 2 & 2.2 & & & \\
\hline Gram-positive bacteria & 25 & 27.7 & & & \\
\hline Staphylococcus aureus & 17 & 18.9 & & & \\
\hline Group $\beta$ Streptococci & 4 & 4.4 & & & \\
\hline Clostridium perfringes (anaerobic) & 2 & 2.2 & & & \\
\hline Staphylococcus epidermidis & 2 & 2.2 & & & \\
\hline Yeasts: Candida albicans & 5 & 5.6 & & & \\
\hline Total & 90 & 100 & & & \\
\hline
\end{tabular}

Table.4 The frequency of microorganisms isolated from 70 patients had monomicrobial culture growth.

\begin{tabular}{|c|c|c|c|c|c|c|c|c|c|}
\hline \multirow{2}{*}{ Microorganism } & \multicolumn{2}{|c|}{ Females } & \multicolumn{2}{|c|}{ Males } & \multicolumn{2}{|c|}{ Total } & \multirow{2}{*}{$\begin{array}{c}P_{-} \\
\text {Value }\end{array}$} & \multirow{2}{*}{ df } & \multirow{2}{*}{$\begin{array}{l}\text { Asymp. } \\
\text { Sig. }\end{array}$} \\
\hline & N. & $\%$ & $\mathbf{N}$. & $\%$ & N. & $\%$ & & & \\
\hline P. aeruginosa & 16 & 22.9 & 15 & 21.4 & 31 & 44.3 & \multirow{7}{*}{4.59} & \multirow{7}{*}{5} & \multirow{7}{*}{.47} \\
\hline S. aureus & 6 & 8.6 & 7 & 10 & 13 & 18.6 & & & \\
\hline E.coli & 2 & 2.9 & 8 & 11.4 & 10 & 14.3 & & & \\
\hline K. pneumonia & 3 & 4.3 & 6 & 8.6 & 9 & 12.8 & & & \\
\hline C. albicans & 1 & 1.4 & 4 & 5.7 & 5 & 7.1 & & & \\
\hline $\begin{array}{l}\text { Group } \beta \\
\text { Streptococci }\end{array}$ & 1 & 1.4 & 1 & 1.4 & 2 & 2.9 & & & \\
\hline Total & 29 & 41.4 & 41 & 58.6 & 70 & 100 & & & \\
\hline
\end{tabular}


Table.5 Frequency of microorganisms isolated from 10 patients had Polymicrobial growth cultures

\begin{tabular}{|c|c|c|c|c|c|}
\hline Polymicrobial infection & $\begin{array}{l}\text { No. of } \\
\text { cases }\end{array}$ & $\%$ & $\underset{\text { Value }}{P_{-}}$ & df & $\begin{array}{l}\text { Asymp. } \\
\text { Sig. }\end{array}$ \\
\hline S. aureus +P. mirabilis & 2 & 20 & \multirow{8}{*}{1.200} & \multirow{8}{*}{6} & \multirow{8}{*}{.977} \\
\hline P. aeruginosa + P. mirabilis & 2 & 20 & & & \\
\hline Group $\beta$ Streptococci $+C$. perfringes & 2 & 20 & & & \\
\hline S. epidermidis $+K$. pneumonia & 1 & 10 & & & \\
\hline$P$. aeruginosa $+B$. fragilis & $\mathbf{1}$ & 10 & & & \\
\hline S. aureus + B. fragilis & 1 & 10 & & & \\
\hline S. aureus + S. epidermidis & 1 & 10 & & & \\
\hline Total & 10 & 100 & & & \\
\hline
\end{tabular}

Table.6 Effect of Kleinia adora and Juniperus procera plant extracts on some isolated bacteria (inhibition zone in $\mathrm{mm}$ )

\begin{tabular}{|l|c|c|c|c|c|c|}
\hline \multirow{2}{*}{ Bacteria } & \multicolumn{3}{|c|}{ Kleinia adora } & \multicolumn{3}{c|}{ Juniperus procera } \\
\cline { 2 - 7 } & $\begin{array}{c}\text { C.W } \\
\text { extract }\end{array}$ & $\begin{array}{c}\text { H.W } \\
\text { extract }\end{array}$ & $\begin{array}{c}\text { Methanolic } \\
\text { extract }\end{array}$ & $\begin{array}{c}\text { C.W } \\
\text { extract }\end{array}$ & $\begin{array}{c}\text { H.W } \\
\text { extract }\end{array}$ & $\begin{array}{c}\text { Methanolic } \\
\text { extract }\end{array}$ \\
\hline P. aeruginosa & 29 & 15 & 14 & 10 & 28 & 30 \\
\hline S. aureus & 30 & 12 & 13 & 12 & 31 & 30 \\
\hline E. coli & 28 & 17 & 16 & 9 & 29 & 29 \\
\hline K. pneumonia & 29 & 14 & 14 & 13 & 28 & 29 \\
\hline
\end{tabular}

Increase in ratio of Gram-negative in this study may be refer to immunocompromised were highly susceptible to hospital-acquired infections, either after colonization with environmental strains or followed invasive surgical, and exert their pathogenic effects by producing endotoxin (Hunt, 2003).

This study showed that the most commonly isolated microorganisms among DFI patients were $P$. aeruginosa $37.8 \%$ of patients followed by $S$. aureus in $18.9 \%$ of patients. Patients who had received prolonged or inappropriate or broad-spectrum antibiotics or had long hospitalization, chronic wound or surgical procedure were most likely to have infection and bacterial colonization such as $P$. aeruginosa and multiple resistant S. aureus (Vandepitte, 2003). These $S$. aureus infections were able to develop due to exposure to the contaminated hands of caregivers rather than to the overuse of antibiotics (Hartemann, et al., 2004).

Basset, et al., found that $P$. aeruginosa infection is especially more prevalent among 
patients with ulcers and intravenous drug addiction (Basset, et al., 1973). Whereas sneakers to ulcer and produce several substances that are thought to enhance the colonization and infection of host tissue. These substances together with a variety of virulence factors, including lipopolysaccharide, exotoxin A, leukocidin, extracellular slime, proteases, phospholipase, and several other enzymes make $P$. aeruginosa the most clinically significant bacteria among DFU patients (Bodey, et al., 1983).

In Saudi Arabia, El-Tahawy, (2000) found that $S$. aureus was the commonest isolate being recovered from $28 \%$ of cases and $P$. aeruginosa $22 \%$ of cases. Low P. mirabilis and $S$. aureus isolated rates in this study may refer to patients who had received antibiotics before specimen collection.

In this study found that rate $E$. coli isolated of DFI was in concurrence with Kuwait study with little different in number of study patients (Abdulrazak, et al., 2005), and in contrast, in rate $K$. pneumonia isolated was low in Kuwait study may be attributable to used antibiotics, number of patients, site of specimens collection, samples collected methods, media used for isolation and identification criteria.

The results of the present study showed that two anaerobic bacteria were isolated during this investigation; $B$. fragilis $2.2 \%$ and $C$. perfringes $2.2 \%$. This finding is in agreement with (Kajetan, et al., 1995; Calhoun, et al., 2002; Slater, et al., 2004 and Hartemann, et al., 2004) who found that the isolation rate of anaerobic bacteria was very low. Low isolation rates of anaerobic bacteria may be due to the depth of infection and previous treatment of patients with multiple antibiotics (Hartemann, et al., 2004).
The results of the present study found that $5.6 \%$ of patients had fungal infection. The only isolated fungi was $C$. albicans,. Similar observations were also reported by (Kajetan, et al., 1995; El-Tahawy, 2000 and Abdulrazak, et al., 2005).

Our study showed that the polymicrobial infections were low $13 \%$ than monomicrobial infections $87 \%$ as shown as in Table 6 and 7. Low rate of polymicrobial isolates may be due to competitive metabolism, toxins, intracellular replication, or antigen-antibody response (Ayton, 1985).

In this study it was found that most of the polymicrobial infections were caused by $P$. aeruginosa with $B$. fragilis and $S$. aureus with $B$. fragilis and Group $\beta$ Streptococci with $C$. perfringes. The bacteria are thought to be synergistic and form biofilms on the surface of chronic wounds (Gerding, 1995). This allows anaerobes to survive on wound surfaces and supports growth of bacteria not normally considered pathogenic (Bowler and Davies, 1999). Decrease rates of polymicrobial infection and isolated pathogens in DFI patients may be attributable to the lack of severity of some infections and the low virulence of isolated microorganisms (Abdulrazak, et al., 2005).

The second goal in this study was to determine the effect of some medicinal plant extracts collected from Taiz province and some chemical antiseptics used in Taiz Hospitals against some isolated microorganisms. The medicinal plant extracts of Jatropha curcas, Calotropis procera, Ziziphus spina-christii, Copparis catilaginea - decne, Pulicaria undulate, Tribulus terrestris, Withania somnifera, Chenopodium murale and Pergularia tomentosa were inactive against most common isolated bacteria $P$. aeruginosa, $S$. aureus, E. coli and $K$. pneumoniae. 
These findings may be attribute to these plants don't have any active compounds which effect on tested bacteria, used methods in extraction, and time period of plants collection. While water plant extracts of Kleinia adora and Juniperus procera had activity against tested bacteria.

The cold water plant extracts of Kleinia adora was active against isolated bacteria, while methanolic and hot water extracts had slight affect on isolated bacteria. This may be referring to insoluble active materials with methanol or hot water.

In contrast the methanolic and hot water extracts of Juniperus procera plant were more effective against isolated bacteria from cold water extract (Tomei, et al., 2003; Lazrek, et al., 2005 and Rustaiyan, et al., 2006).

\section{References}

Abdulrazak, A., Bitar, Z.I., Al-shamali, A.A. and Lubna, Ahmed, M. 2005. Bacteriological study of diabetic foot infections. Kuwait $J$ of Diabet and it is Complic., 19: 138-141.

Aldbai, A. and Alkhalidi, A. 1996. Medicinal and aromatic plants in Yemen. Ebadi Library for Publication and Distribution. Sana'a.

Al-Samurai, T.H. 1995. Microbiology, Higher Education Ministry, Health institutes, Damask, Vol II 179PP. (article in Arabic).

Ayton, M. 1985. Wounds that won't heal. Nurs Times. 81: 9 -16.

Basset, D.J., Dickson, J.A. and Hunt, G.H. 1973. Infection of holter valve by Pseudomonas contaminated chlorhexidine. Lancet, 1: 1263-1264.

Bennett, K.W. 1999. American Diabetes association. Diabetic Care, 14: 15-45.

Bodey, G.P., Bolivar, R. and Fainstein, V. 1983. Infection caused by
Pseudomonas aerugnosa. Rev. Infect. Dis., 5: 279-313.

Bowler, P.G. and Davies, B.J. 1999. The microbiology of infected and noninfected leg ulcers. Int. J. Dermatol., 38: 8-573.

Caputo, G.M., Joshi, N. and Weitekamp, M.R. 1997. Foot infections in patients with diabetes. Am. Fam. Physician, 56(1): 195-202.

Cheesbrough, M. 2000. District Laboratory practice in Tropical Countries, Vol II, Cambridge Unir Press, Gopsons Paper, Limited, NOIDA, India.

El-Tahawy, A.T. 2000. Bacteriology of diabetic foot. Saudi Med. J., 21: 7344.

Environmental Protection Authority. 2002. Wild plants from Yemen. (article in Arabic).

Frykberg, R.G. 2003. An evidence-based approach to diabetic infections. Am. J. Surg., 186: 44-54.

Gerding, D.N. 1995. Foot infections in diabetic patients: the role of anaerobes. Clin. Infect. Dis., 20(2): 8283.

Hartemann, Heurtier, A., Robert, J., Jacqueminet, S., Ha Van, G., Golmard, J.L. and Jarlier, V. 2004. Diabetic foot ulcer and multidrugresistant organisms: risk factors and impact. Diabet Med., 21: 15 -710.

Hunt, J.A. 2003. Diabetic Complication. Diabet Med., 9: 113-116.

Johonson, D.G. and Citron, L.G. 2002. Lower extremity amputation among persons with Diabetic Mellitus. Washington. 8-11.

Josef, G. and Nesbit, V. 1998. Foot Care. J. Am. Diabet. Associ., 18: 64-79.

Joshi, N. 1999. Infections in patients with diabetes mellitus. N. Engl J. Med., 341: 1906-1912.

Kajetan, M., Konkoly, T.M. and Jermendy, G. 1995. Experience with 
microbiological studies of the diabetic foot. Hungarian Osztaly Pub. Med., 136(40): $2161-2164$.

Lazrek, H.B., Jana, M., Michel, J.B., Eddouks, M. 2005. Aqueous extracts of some medicinal plants. $J$. Phytotherapy Res., 18(4): 26-48.

Lipske, B.A., Berendt, A.R., Deery, H.G., Embil, J.M., Joseph, W.S. and Karchmer, A.W. 2005. Diagnosis and treatment of diabetic foot infections. J. Am. Podiater Med. Assoe., 95: 183210.

Marble and Alexander. 1985. Diabetes Mellitus.12th ed. Philadelphia: Lea, Jebiger.12-14.

Palumbo, P.J. and Melton, L.J. 1985. Peripheral Vascular Disease and Diabetes. In: Diabetes in America, Data Compiled 1984 (NIH publ. No. 85-1468) p. 1US Govt Printing Office, Washington DC3.

Rubaiaan, K. 2008. Diabetes facts and figures. Al-Riyadh Newspaper Friday, 23/ 1429 corresponds to 21 / November / 2008 - No. 14760. (article in Arabic).

Rustaiyan, A., Moazami, N., Masoudi, S. and Bamasian, S. 2006. Methanolic and aqueous extract Methodes of some medicinal plants in Iran. Flavour and Fragrance J., 41: 5-29.

Sharma, V.K., Khadka, P.B., Joshi, A. and Sharma, R. 2006. Common pathogens isolated in diabetic foot infection in Bir Hospital. Nepal Kathmandu Univ. Med. J., 15(3): 295-301.

Slater, R.A., lazarovitch, T., Boldur, I., Ramot, Y., Buches, A. and Weiss, M. 2004. Swab cultures accurately identify bacterial pathogens in diabetic foot wounds not involving bone. Diabet Med., 21: 9 -705.

Tomei, P.E., Byrne, M.J. and Zani, A. 2003. Anti-microbial activity of plant extracts from the wild flora in southeastern Asia. Phytoecol. Biochem., 2: 7-42.

Vandepitte, J. 2003. Basic Laboratory Procedures in Clinical Bacteriology. 2nd Ed. Who, Geneva.

White, R.J., Cooper, R. and Kingsley, A. 2001. Wound colonization and infection: the role of topical antimicrobials. Br. J. Nurs., 10: 78 563.

\section{How to cite this article:}

Mohammed A. Al-Hegami, Saeed M.S. Alghalibi and Abdullah Al-Mamari. 2016. Microorganisms Responsible of Diabetic Foot Infection in Taiz City, Yemen. Int.J.Curr.Microbiol.App.Sci. 5(7): 431-441. doi: http://dx.doi.org/10.20546/ijcmas.2016.507.047 